\title{
The Strategy of Strengthening Traditional Market in Providing Right to Work
}

\author{
I Nyoman Sukandia, Anak Agung Istri Agung \\ Faculty of Law \\ Universitas Warmadewa \\ Denpasar-Bali, Indonesia \\ nyoman_sukandia@gmail.com
}

\begin{abstract}
The existence of modern market in the area of tourism has been a wide concern in Bali. It is predicted that its existence can bring some negative impacts, especially eroding the existence of traditional market and reducing the right of work of traders in traditional markets. This study is aimed to investigate the right of works of traditional traders and to propose some efforts to strengthen them to be more competitive. This study used normative legal method, and the legal materials used included local government regulations on regulating both modern and traditional markets. Data were also collected through interview and field observation. The results showed that the existence of modern markets in the tourism sector has eroded the existence of traditional markets and diminished the right to work of traders in the traditional markets. In order to keep the existence of the traditional markets, strategies to strengthen model in the form of partnership business management, empowerment, and standardizing market services should be implemented. These strategies become the responsibilities to the government and other stakeholders, such as corporate, financial institutions, and communities.
\end{abstract}

Keywords-market strengthening strategies; the right to work; traditional markets; toursim sector

\section{INTRODUCTION}

Previous study has shown that the rapid growth and development of the tourism industry in Bali has bring positive and negative impacts on Bali. Examples of the positive impacts are the increased tax revenues, employment opportunities and adequate infrastructure construction. However, on the other hand, examples of the negative impacts are environmental damage, which naturally affects ecosystems such as the occurrence of air pollution, exploitation of natural resources and damage to coral reefs [1,2]. It is also noted that culture tourism has become mass tourism and did not care so much about Tri Hita Karana (the philosophy of Tri Hita Karana is the philosophy of Balinese in which human beings balance their lives between God, humans and nature) [3] as well as tends to touristic culture [4].

The existence of traditional market sand art markets as mentioned above, which are generally developed traditionally is feared to be more marginalized and less competitive in terms of convenience with the emergence of many modern markets. The examples of modern markets are minimarket, supermarket, department store, and hypermarket and also whole sale. They tend growing rapidly are not only in the tourism areas but also up to the rural areas. Moreover, the existence of such modern markets are coupled with high standards both related to skill, technology and service standard. The main characteristics of modern markets include: fixed prices (without bargaining process), the availability of wide range variety of products, comfort level (since mostly all modern markets have air conditioning and good or brand new buildings) and high performance standard services from the shopkeeper. Unfortunately, the explained characteristics above tend not to be possessed by traditional market services.

In terms of employment, the positive impact of the modern markets existence in Bali, of course, those will create more job opportunities. However, on the other hand, such existence may cause the trades of traditional markets to lose their jobs due to the shift of market share from traditional market to modern market. This condition is a dilemma. On one side, the presence of modern markets in the era of globalization cannot be avoided and is a necessity. But on the other side, it is undeniable that the traders' right to work in traditional markets will gradually diminishing and even, it is not impossible, they have to close the business so that traders in traditional markets will lose their right to work.

The purpose of this article to examine and analyze the right to work for traditional traders and traditional workers in tourism activities in Bali, as well as to discuss the relevant regulatory model in order to strengthen the existence of traditional markets and keep the right to work of traditional traders still exist supported by sufficient capital, skills and technology similar with the modern markets. Two legal problems discussed in this article related with legal basis for the right to work of traders and workers of traditional markets in the global market competition and the regulatory model of strengthening traditional market in relation to the existence of the right to work for traders and workers of traditional markets in the Bali global tourism.

\section{METHOD}

This study employs normative legal research which is conducted methodologically, systematically and consistently [5]. The approaches used in this study are the legislation, conceptual and comparative approaches. Furthermore, 
qualitative descriptive analysis is used as the analysis technique.

\section{RESULT AND DISCUSSION}

\section{A. Policies for Traditional Market Strengthening and Modern Market through the Right to Work}

Recognition of cultural in the politics of tourism law can be seen from the perspective of realizing the ideal of law (rechtsidee). The perspective of the ideal of law on the urgency of cultural recognition in national and local perspective including tourism is important to be concerned. It is because the legal order implemented in a society is essentially elaboration of the ideal of law embraced in society into the tools of the various positive law rules, legal institutions and processes [6]. The neglect of the ideal of law creates flexibility for the workings of foreign ideologies in perpetuating the ideals of Indonesian law (Pancasila), destroying the life of the Indonesian nation, destroying the identity marker and the substance of Indonesian identity [7]. If the existence of modern market, in the context of Balinese tourism development, to displace the existence of traditional market, maybe such phenomenon is one of the sign that there has been a destruction on the identity marker of Indonesia. It is because the traditional market is actually one of the real form of local wisdom in which connects socio-economic interaction that not only between humans but also the harmony relationship between human beings and nature as well as God as. In connection between human being and God, there is always a place of worship called "Pura Melanting" in traditional markets in Bali. Pura Melanting is a Hindu holy place to express a sense of gratitude to God Almighty who has bestowed sustenance and prosperity for traders and workers in traditional markets.

The worries of the erosion of traditional markets are not without a clear reason. The Human Rights National Commission (Komisi Nasional Hak Asasi Manusia) study shows that the rapid development of modern markets negative impacts the growth and labor of traditional markets throughout Indonesia. The Human Rights National Commission records that there are 13.450 markets with 12.625 .000 traders. The number of modern markets declines the turnover of traditional market sales. The results show that traditional markets development has grown negatively by $8 \%$. In fact, there is traditional market which sales turnover is reduced up to $75 \%$. Meanwhile, the modern markets grow positively around $31.4 \%$. The growth of modern market has wide impact on the destruction of traditional markets, one of which is traditional market consumers are started to move to modern markets.

The pressure faced by the traditional markets upon its existence is not only influenced by the growth of modern markets such as Minimarket, Supermarket and Hypermarket, but also because of internal factors of the traditional market itself. Some examples of such internal factors are: the poor infrastructure (mostly dirty, muddy, smell) and the poor management. Meanwhile one example of the external factors is the presence of many modern markets is not accompanied by zoning and good spatial so eventually benefit only to the modern market [8]. In addition, indeed, standardization and the problem of effectiveness and efficiency often claimed as the characteristic of globalization that is not only discourse in developing countries like Indonesia but also in developed countries like the UK. In pursuing "Making Globalization a Force for Good", it is important to understand that there may be losers and winners. Nevertheless, the good government will also display effective government, touching on rule, law and order, corruption, and human rights [9].

From the above explanation, it seems that traditional markets are the looser. In relation to the protection of the right to work as mandated by Article 23 of the UDHR and Article 6 of the ICESCR, it should be the state obliged and responsible to take concrete measures as good as possible in the form of policy models, training facilities and technical assistance in order to strengthen the existence of traditional markets. Therefore, employment opportunities that fulfill the people' rights of work in decent and dignified remain available in traditional markets. The states, in this context the local governments, should construct policies and solutions that are unidirectional. Policies that provide solution, access to justice policies that are sensitive to the fate of the traditional market and are not only for modern market are urgently needed. The policy is in fact an implementation of the state's obligations in the fulfillment of economic, social and cultural rights related to the right to work and the right in work.

Local Government of Bali Province through Bali Province Regulation No. 2 of 2012 on Bali Cultural Tourism has actually been stipulated concerning the maintenance culture in tourism development situation. The consideration of this regulation states that: a. Balinese culture as part of Indonesian culture is the main foundation of Balinese tourism development, which is capable of mobilizing tourism potential in the local, national, and global life dynamics; b. the development of Bali tourism aims to encourage equal distribution of business opportunities and obtain maximum benefits for the welfare of society so that the ideal of tourism for Bali can be achieved and not vice versa which is Bali for tourism.

It is also explained in such regional regulations that Bali Culture Tourism is a Bali tourism based on Balinese Culture inspired by the teachings of Hinduism and the Tri Hita Karana philosophy as the main potential by using tourism as the vehicle of its actualization. Such thing results in a dynamic interrelationship between tourism and culture that makes them grow synergistically, harmoniously and sustainably to be able to provide prosperity to society, cultural and environmental sustainability. Tri Hita Karana as the life philosophy of Balinese society contains three elements that build balance and harmony relationships between human with God, human with human, and human with its environment. Hence, such balance and harmony relationships become source of prosperity, peace, and happiness for human life.

Some policies are constructed, revised and developed by the Bali Provincial Government for tourism development in Bali. Such steps conducted based on Balinese culture Bali mentioned above, which is called Tri Hita Karana. The aim of such steps is to create social welfare and happy life of human beings. Some examples of policies as explained above are as follow: (1) Bali Province Regional Regulation No. 6 of 2009 
on Long Term of Regional Development Planning of Bali Province (RPJPD) Year 2005-2025, (2) Bali Province Regional Regulation No. 10 of 2015 on Master Plan of Regional Tourism Development of Bali Province Year 2015-2029.

As mentioned before, Bali is famous as the island of the thousands temple and the island of God. That is actually referring to the Balinese society which majority is Hindu. Related to that, the tourism policies in Bali synergize with Balinese culture that breathes Hinduism. Balinese culture has its own characteristics. For example, every activities of Balinese community are based on cultures related to Hindu religion. Furthermore, the culture also reflected in the activities of the people of Bali in traditional markets.

Traditional markets in Bali trade a wide range of basic necessities, especially, they trade also products for religious activities such as young coconut leaves, umbrella for temple, flower to make canang (one example of offerings), traditional clothes (kebaya, udeng, saput, kammen), until various unique fruits, cakes and foods (tumpeng, saur from coconut meat, jajanuli).Traders in traditional markets hung up their life so heavily on the buyers of the Balinese themselves as their main consumers. So the existence of this traditional market is very important to be maintained. Obviously, the existence of traditional markets also gives the right of traders and workers to get their job (the right to work). Governments are obliged to implement the rights of everyone to get their jobs to the best, including in traditional markets. The existence of the right to work of such traditional market traders is depending on the existence of traditional market management, in addition to the commitment, willingness and firmness and hard work of the local leaders to make the traditional markets become better and dignified.

In addition to the above mentioned regional regulations, concrete manifestation of local government related to the strengthening of traditional markets can also be seen from the below regulations in the level of Regency/City as follow: (1) Denpasar Mayor's Regulation No. 9 of 2009 on Structuring and Fostering Traditional Markets, Shopping Centers and Modern Stores,

(2) Regional Regulation of Badung Regency No. 7 of 2012 on Structuring and Fostering Traditional Markets, Shopping Centers and Modern Stores.

The vision of legal politic that underlies traditional market and modern market regulations policies the Regional Government of Regency/City who has commitment to realize a just and prosperous society based on Pancasila and the 1945 Indonesian. It is necessary to implement economic development in a sustainable region based on economic democracy to achieve the goals of the state. In line with that vision, the traditional markets, shopping centers and modern stores are places where the sale and purchase of goods are conducted which implementation need to be organized and trained so as to grow and develop conducive, harmonious, fair and mutually beneficial and prevent unhealthy business practices.

With the development of modern markets, small, medium and large scale, on the other hand, the existence of traditional markets also need to be strengthened and empowered. Thus, at the end, the existence of traditional markets will develop in harmony with the presence of modern markets. In order to realize such harmonization, it is necessary to have guidance concerning the norms of justice, how to create mutual benefit without pressure and the development of partnerships on the implementation of traditional markets and modern markets. Freedom of work is the right of society to be encouraged through the access of competitive and just opportunity.

\section{B. Strategy for Strengthening Traditional Market through the Right to Work}

Based on various policies in Bali, both at the provincial and regency/city levels, it can be observed that the regulatory model of traditional market strengthening in relation to the modern market, the substances include: arrangement of location and distance of establishment, socioeconomic requirements, floor area, type of goods, parking lot, working hours, capital requirements, feasibility studies, supply of goods to modern stores, business partnerships, licensing, empowerment, fostering and supervision, rights, liability and prohibition, administrative sanctions, as well as criminal provisions.

With regard to empowerment, fostering and supervision of traditional markets in relation to modern markets, Regional Regulation of Jembrana Regency No. 8 of 2010 basically set provisions in line with Regional Regulation of Badung Regency No. 7 of 2012.

Furthermore, the Regulation of Mayor of Denpasar Number 9 of 2009 which almost in line with the Regional Regulation of Badung Regency Number 7 of 2012 regulates the substance of business partnership relating to the existence of modern market and the sustainability of business of the local community. Model of the traditional market strengthening in Denpasar city is also done in the form of moratorium policy, through Mayor Regulation Number 9 of 2009 and Decree of Mayor Number 49 of 2011. Another strengthening model conducted by the Government of Denpasar is through the promotion of traditional markets as city tour destination so that traditional markets can still compete with the modern markets. Various strengthening and fostering things are done to traditional market traders such as: training to improve the quality of human resources and training related to ethical attitude, for example teach the traders or shopkeepers to be dare to apologize when making mistakes. In the framework of strengthening traditional markets, there are 16 traditional markets are managed by the Denpasar City Government, while 32 markets are managed by local custom rules, which are supported by the government to develop their market management. One of the traditional markets that have gained strength and has become a tourist destination both for foreign and domestic tourists is Sindu Market which is located in Sanur Village, Denpasar-Bali.

The regulatory models on strengthening traditional market as already implemented by the Denpasar City Government actually reflect the steps as mandated by the Universal Declaration of Human Rights (UDHR) and International Covenant on Economic, Social and Cultural Rights (ICESCR), 
the 1945 Indonesian constitution, the Indonesian Human Rights Law and the Indonesian Manpower Law which essentially provide protection and recognition of the right to work. In the more concrete context, measures that can be done by the government as a regulatory model on strengthening or policy of the right to work for traders and workers of traditional market workers are as follow: strengthening in the form of physical appearance of the market, strengthening the human resources standards, as well as strengthening of financial and supervision. Strengthening of physical appearance of the traditional markets includes the improvement of market arrangement, structuring the trader's zone, parking area, hygiene management and market safety. Strengthening of human resources standards include training of service standard, ethics, financial management, and management of products. Furthermore, the financial strengthening includes access to capital in the form of partnerships from various financial institutions. In addition, supervision strengthening includes ongoing fostering and supervision. Such strengthening models are not only become the duty and responsibility of the government but also a joint responsibility of all stakeholders.

\section{CONCLUSIONS}

The arrangements of the right to work of traders and workers in the traditional market of Bali-Indonesia, in the local and national perspectives, are regulated under Regency/Municipal Regulations, Provincial Regulations of Bali, Presidential Regulation, Trade Minister Regulation, Indonesian Manpower Law, Indonesian Human Rights Law and 1945 Indonesian Constitution which relevant to Article 6 of the ICESCR and Article 23 of the UDHR. The regulatory model on strengthening traditional market in relation to existence of the right to work in traditional markets in the global competition in Bali's tourism area is done through policy models which substance regulate strengthening of the physical appearance of the market, human resource standards, financial partnership and supervision.

In order to strengthen the traditional markets and to keep the existence of the right to work, it is expected that Governments to give their willingness, firmness and hard work commitment, as well as the Regional Government, especially, to implement the technical guidance, training, and constructing the policy model as the real form of protection and recognition of the right to work as arranged in UDHR, ICESCR as well as the 1945 Indonesian Constitution.

\section{ACKNOWLEDGEMENT}

The author would like to thank all the parties who have helped and contributed in the writing of this article, both those who contribute in the form of funding and critical ideas. Hopefully this paper can be useful theoretically and practically for the addition and development of knowledge, especially in the field of legal science.

\section{REFERENCES}

[1] D. N. K. Supasti, Tourism and Environment; Toward Promoting Sustainable Development of Tourist; A Human Rights Perspective. Indonesia Law Review. Year 2 vol. 1, January - April 2012, 2012.

[2] N. K. Supasti and M. Sarjana. Marine Biota and Biodiversity: A Sustainable Tourism Perspective. Journal of Advances in Tropical Biodiversity and Environmental Sciences. Vol. 1.No. 1. February 2017. Institute for Research Community Services. Udayana University, 2017.

[3] P. J. Hendrik and W. Wardana. Tri Hita Karana The Spirit of Bali. Kepustakaan Populer Gramedia. Jakarta, 2013.

[4] P. Michel, Balinese Identity as Tourist Attraction: Frrom "Cultural Tourism" to "Ajeg Bali" in I Nyoman Darma Putra and Siobhan Campbell. 2015. Recent Developments in Bali Tourism. Culture. Heritage And Landscape in An Open Fortress. Buku Arti. Denpasar Bali, 2015.

[5] J. Ibrahim. Teori Dan Metode Penelitian Hukum Normatif. Banyu Media, Malang, 2005.

[6] Sudantra, I. K., Pengakuan Peradilan Adat Dlam Politik Hukum Kekuasaan Kehakiman. Swasta Nulus. Denpasar, 2016.

[7] Putra, I. B. W., Teori Hukum dengan Orientasi Kebijakan (Policy Oriented Theory of Law) : Pemecahan Problem Konteks dalam Proses Legialasi Indonesia. Udayana University Press. Denpasar, 2016.

[8] Putro, D. A., Quo Vadis Persaingan Pasar Tradisional dan Pasar Modern. Jurnal Jendela Informasi Hukum Bidang Perdagangan. Edisi April 2012. Kementerian Perdagangan Republik Indonesia. Jakarta, 2012.

[9] Maxwell, S., Making Research on Globalization Work For The Poor : A Commentary On Adrian wood's 'Making Globalization Work for The Poor : The 2000 White Paper Reconsidered'. Journal of International Development. J. Int. 16, 939-941. 2004. 